\title{
The Role Of Indictment Of Public ProsecutorIn Eradication Of The Case Of CorruptionIn Indonesian Criminal Justice System
}

\author{
Oksidelfa Yanto*, Erma Rusdiana, Nani Widya Sari,Yulita Pujilestari \\ Magister of Law Pamulang University, Faculty of Law Trunojoyo Madura \\ University, Faculty of Economic Pamulang University, Faculty of Teacher \\ Training and Education Pamulang University. \\ *Corresponding author:dosen00240@unpam.ac.id
}

\begin{abstract}
This research is purposed to determine the role of the prosecutor as a law enforcement agency in the field of prosecution and also wants to know the role of the public prosecutor's indictment in law enforcement of corruption crimes in the Indonesian criminal justice system. The method that I use in this writing is a normative juridical legal research method using secondary data derived from legal materials that are relevant to the problem under study. The results showed that the role of prosecutors as law enforcement agencies in the field of prosecution given the authority to make indictments especially in terms of eradicating corruption has a very important meaning in realizing the achievement of legal objectives. This is because prosecutors are part of the sub criminal justice system in Indonesia. As a sub-system the prosecutor has the authority to eradicate corruption by providing the most severe criminal charges to perpetrators of corruption through his indictment.
\end{abstract}

Keywords: Attorney, Indictment, Criminal Justice System.

\begin{abstract}
Abstrak
Penelitian ini bertujuan untuk mengetahui peran kejaksaan sebagai lembaga penegak hukum bidang penuntutan dan juga ingin mengetahui peran surat dakwaan jaksa penuntut umum dalam penegakan hukum kejahatan korupsi dalam sistem peradilan pidana Indonesia. Metode yang penulis gunakan dalam penulisan ini adalah metode penelitian hukum yuridis normatif dengan menggunakan data sekunder yang berasal dari bahan-bahan hukum yang relevan dengan masalah yang diteliti. Hasil penelitian menunjukkan bahwa peran jaksa sebagai lembaga penegak hukum bidang penuntutan yang diberi kewenangan membuat surat dakwaan khususnya dalam hal pemberantasan korupsi memiliki arti yang sangat penting dalam mewujudkan tercapainya tujuan hukum. Hal ini dikarenakan jaksa merupakan bagian dari sub sistem peradilan pidana yang ada di Indonesia. Sebagai sub sistem jaksa memiliki kewenangan dalam hal pemberantasan korupsi dengan memberikan tuntutan pidana paling berat kepada pelaku korupsi melalui surat dakwaannya.
\end{abstract}

Kata Kunci: Jaksa, Surat Dakwaan, Sistem Peradilan Pidana. 


\section{Introduction}

Indonesia is one of the countries which until now is still shrouded in black clouds of corruption. Corruption continues to occur in various fields. The culprit comes one after another. Various efforts continue to be made in eradicating corruption. For example, the government established legislation on criminal acts of corruption. The government also formed various bodies to overcome and prevent corruption. Even the countries have formed the Corruption Eradication Commission (KPK) as a powerful effort in tackling corruption crimes. However, various laws, agencies and commissions that were formed have apparently not made Indonesia a corruption-free country. Then how to eliminate the black cloud of corruption from Indonesia? One thing that must be done by the government is to maximize the role of institutions or law enforcement institutions in this country.

In the Indonesian criminal justice system there are institutions that carry out law enforcement, namely the police, prosecutors, courts and correctional institutions. The four law enforcement institutions are known as the criminal justice system or integrated criminal justice system. In carrying out its duties and responsibilities, these law enforcement institutions carry out guidelines based on the provisions of legislation, such as Law Number 2 of 2002 concerning the National Police of the Republic of Indonesia, Law Number 16 of 2004 concerning the Prosecutor's Office of the Republic of Indonesia, Law Number 48 of 2009 concerning the Judicial Power of the Republic of Indonesia, and Law Number 12 of 1995 concerning Correctional Institutions. Besides that, it is also guided by the provisions of Law Number 8 of 1981 concerning the Criminal Procedure Code (KUHAP) and several other provisions of laws and regulations. By referring to the provisions of the Act referred to above, it is expected that these law enforcement institutions will be able to carry out their duties well in meeting the expectations of the community.

Especially for the Attorney General's office in law enforcement 
in this case is to carry out prosecution. "Article 1 paragraph (1) of Law Number 16 of 2004 concerning the Prosecutor's Office of the Republic of Indonesia states that:" "Prosecutors are functional officials authorized by the Law to acting as a public prosecutor and implementing a court decision that has obtained permanent legal force and other authority under the Act.

The Prosecutor's Office is a nondepartmental institution, which means it is not under any ministry. The top of the prosecutor's leadership is held by the Attorney General who is responsible for the President. In contrast to the prosecutor's organizational structure in the Netherlands, England and America which is generally under the Ministry of Law. The position of the Attorney General is at the level of the Minister, therefore the Prosecutor's Office is not under any Ministry. The Attorney General leads the prosecutor's office which is divided into legal areas ranging from the Provincial (High Prosecutor) level to the District (District Prosecutor's Office) in all regions of Indonesia.
This system of distribution of jurisdictions mimics the territorial division system in the Netherlands, where the Netherlands has 5 (five) High Prosecutors, each of which has between 4 (four) to 5 (five) Prosecutors equivalent to the District level (District Prosecutor's Office). (Didit Ferianto Pilok, 2013: 145146).

Thus, in the criminal justice system based on Article 1 paragraph (1) of Law Number 16 of 2004 concerning the Prosecutor's Office of the Republic of Indonesia the main task of the Prosecutor's Office is to prosecute every legal case. Absolute authority is given to the prosecutor for prosecution. This authority is not owned by other institutions. It is not wrong then that in the criminal justice system we mention that there are no criminal cases that can be tried in court without the case being filed by the public prosecutor. This can be seen in the provisions of "Article 13, 14, 15 of the Criminal Procedure Code (KUHAP)." The prosecutor was authorized to prosecute anyone who alleged a criminal act. Prosecutors are law 
enforcement institutions that have the right to sue in an Indonesian legal state. Indeed, as a law enforcer, the Prosecutor's Office of the Republic of Indonesia is a government institution whose role is to carry out independent state power, especially the implementation of duties and authorities in the field of prosecution and carrying out the duties and authorities in the field of investigation and prosecution.

If you see other provisions regarding prosecutors as public prosecutors, then in Law Number 16 of 2004 concerning the Prosecutor's Office of the Republic of Indonesia, Article 2 paragraph (1) also affirms that "The Prosecutor's Office of the Republic of Indonesia is a government institution that carries out state power in other fields of prosecution and authority according to the Act. "" Then also in Article 30 Paragraph (3) of Law Number 16 of 2004 concerning the Prosecutor of the Republic of Indonesia, the prosecutor of the Republic of Indonesia also plays a role in the field of public order and peace, the prosecutor's office also organizes: a. community; b) Safeguarding law enforcement policies; Safeguarding circulation of printed goods; d) Supervision of the flow of trust that can endanger the community and the State; e) Prevention of abuse and / or blasphemy of religion; f) Research and development of criminal laws and statistics.

Then in the explanation of the Law of the Republic of Indonesia Number 16 of 2004 concerning the Prosecutor of the Republic of Indonesia, the general section states that in carrying out its functions, duties and authority, the prosecutor of the Republic of Indonesia as a government institution that implements state power in prosecution must be able to realize legal certainty, order law, justice and truth based on law and heed religious norms, politeness, and decency, and must explore human, legal, and justice values that live in society.

Therefore, in carrying out its functions, the prosecutor's office must work independently and be free from any intervention, including from the government. It is very 
dangerous if the prosecutor's office works with intervention from other parties. The independence of Prosecutors has so far sparked debate. This cannot be separated from the position of the prosecutor's office as a government institution while its function as a law enforcement institution raises many questions, can the prosecutor's office be able to work independently in carrying out its functions, but the position of the prosecutor's office is part of the government. (Dio Ashar Wicaksana, 2013: 3).

As one of the law enforcement agencies, the prosecutor's office is required to play a role in upholding the rule of law, protecting the public interest, upholding human rights, and eradicating corruption, collusion and nepotism. The role of the prosecutor as a law enforcement institution in the criminal justice system in handling various cases of criminal law is clearly very important and is needed once to realize certainty, justice and benefit of the law. This role begins with conducting an investigation, then prosecuting, until the examination in the court session, legal remedies and ending until the execution. In the investigation phase, for general crimes the prosecutor has the role of carrying out preprosecution activities against the results of activities carried out by police investigators and other investigators. For special criminal offenses, prosecutors act as investigators. While at the prosecution stage the prosecutor's role was to delegate case files to the district court accompanied by an indictment as the basis for the hearing in the trial.

Based on the description above, the problem statement can be made as follows:

1) What is the role of the prosecutor's office as a law enforcement agency in the Indonesian criminal justice system?

2) What is the role of the public prosecutor's indictment in law enforcement of corruption crimes in the Indonesian criminal justice system? 


\section{Research Methods}

The research that the authors make is a type of normative juridical research. Normative juridical research is conducted through library studies to collect and understand secondary data that the author gets through secondary legal materials and primary and tertiary legal materials by understanding the law as a set of positive rules or norms in the system of legislation governing problems in this study.(Soerjono Soekanto \& Sri Mamudji, 1985: 15). The data collected is certainly relevant to the problems that the authors examine, so that after the data is collected, then it is processed and analyzed to answer the problems and problems that exist.

\section{Result and Discussion}

The Role of the Prosecutor as a Prosecution Law Enforcement Agency

As we know that eradicating corruption is a series of actions in order to prevent and also eradicate corruption. This eradication will only succeed if it is carried out through various efforts of coordination, investigation, investigation, examination and prosecution in court. This has become important because since the issuance of Law No. 31 of 1999 as amended by Act No. 20 of 2001 concerning the Eradication of Corruption Crime accompanied by the establishment of the Corruption Eradication Commission (KPK) through Law No. 30 of 2002 concerning the Eradication Commission Corruption Crime, shows that corruption is a special concern for the country. In the context of Indonesia as a legal state, efforts to eradicate corruption committed are part of law enforcement.

Law enforcement is the process of making efforts to uphold or function legal norms as a real guideline for behavior in public and state life. Law enforcement is an effort made to make law both in a narrow formal sense and in a broad material sense as a code of conduct in every legal act, both by the legal subjects concerned and by law enforcement officials who are officially given the task and authority by law - law to guarantee the 
functioning of legal norms that apply in the life of society and the state. (Rudi Indrawan, H. Ahmad Syaufi Rechtidee, 2016 : 36-37).

One of the institutions serving in law enforcement is the prosecutor's institution. In the general explanation, it was explained by the prosecutor's office that the government carries out state power in the field of law enforcement by adhering to the laws and regulations and policies set by the government. Thus the Attorney General is appointed and dismissed by the President and responsible to the President ". The duty and authority of the prosecutor in law enforcement is to conduct investigations on certain criminal acts based on the Law.

In the provisions of Article 139 of the Criminal Procedure Code, it is explained: After the Public Prosecutor receives or receives the results of a complete investigation from the investigator, he immediately determines whether the case file has fulfilled the requirements to be transferred or not delegated to the Court.
Prosecutors are referred to as "officials" who are authorized by law to act as public prosecutors and carry out court decisions that have obtained permanent decisions. (see Article 1 to 1 of Law Number 5 of 1991) concerning the Prosecutor's Office. In Law Number 16 of 2004 Article 1 to 1 ) the Prosecutor is said to be functional officials authorized by law to act as public prosecutors and the implementation of court decisions that have obtained permanent legal force and other powers under the law.

Then Article 2 to 1 is stated: "The Prosecutor's Office of the Republic of Indonesia, hereinafter referred to in this Law, is the prosecutor's office which exercises state power in the field of prosecution and other authorities under the law".

In prosecuting prosecutors act both as state lawyers and community lawyers. In various countries the prosecutor also functions as a protector of public interests so that his attitude towards the suspect or defendant and the person he 
investigates must be objective and impartial. (Moh, 2009: 39).

From a historical approach, prosecutors put themselves in a central position in the investigation. After the proclamation of independence, through Article 12 of the Law on the composition of the Judicial Power in 1948 it was stated explicitly the authority of the prosecutor to carry out investigations / prosecutions. The Constitution of the Republic of Indonesia (RIS) which was established through a Presidential Decree (Keppres No. 48 dated 31 January 1950) which took effect during the sovereignty election on 27 December 1950 stated that the Attorney General / Attorney General's Office had the authority to investigate / prosecute, as well as the HIR. Law No. 5 of 1991 concerning the Principles of the Attorney General's Office in Article 2 gives the prosecutor the authority to carry out further investigations. (Moh. Hatta, 2009: 46).

Investigation according to special provisions of criminal proceedings as referred to in certain Laws as referred to in Article 284 paragraph (2) of the Criminal Procedure Code is carried out by investigators, prosecutors and other authorized investigative officials based on legislation. Investigations, prosecutions and examinations in court proceedings in cases of corruption, are carried out based on the applicable criminal procedure law, unless otherwise stipulated in this law. (Didit Ferianto Pilok,2013:166).

Based on the provisions of the legislation above, it can be said that the duties and authority of the prosecutor in enforcing the law to eradicate corruption are conducting investigations, investigations, prosecutions, carrying out judges' decisions and court decisions and holding other legal actions. Therefore, the role that should be in accordance with the duties and authority of the prosecutor in the field of law enforcement for corruption is conducting investigations, investigations, prosecutions, carrying out judges' decisions and court decisions and other legal actions. 
In carrying out its functions, duties, and authorities, the Prosecutor of the Republic of Indonesia as a government institution that implements state power in the field of prosecution must be able to realize legal certainty, law order, justice and truth based on law and heed religious norms, politeness, and decency, and must explore the values of humanity, law and justice that live in the community (Explanation of Law No. 16 of 2014 concerning the Prosecutor's Office of the Republic of Indonesia). (Rudi Indrawan, $\mathrm{H}$. Ahmad Syaufi Rechtidee, 2016: 43).

The existence of the prosecutor's office is intended as an institution of law enforcement officials in the field of prosecution to realize a sense of justice, legal certainty, and the benefit of the law in the life of the community, nation and state. (Yesmil Anwar dan Adang, 2009: 189).

Finally, the magnitude of the impact of criminal acts of corruption on people's lives, it is very important that the prosecutor's institution plays its role in law enforcement against perpetrators of corruption. This certainly will be a challenge for the prosecutor's institution amid the great expectations of the community to make Indonesia free of corruption. From that, the prosecutor's institution must always improve its performance and professionalism to bring Indonesia into a country free from corruption crimes in the future.

\section{Prosecutor's Office Part of the Indonesian Criminal Justice System}

The criminal justice system is essentially a system that involves relations between several institutions (referred to as subsystems) known as law enforcement agencies. Correctional services in relation to the criminal justice system are often coupled with correction institutions that are placed as post adjudication in the criminal justice system. (Eva Achjani Zulfa, 2017: 63).

As many parties understand the criminal justice system adopted by the Criminal Code. The Criminal Code seems to consist of sub- 
systems which are the stages of the process of resolving cases, investigation sub-systems carried out by the police, prosecution systems carried out by the prosecutor's office, sub-systems of examinations carried out by courts and sub-systems for implementing court decisions carried out by prosecutors and prisons. (Eva Achjani Zulfa, 2017: 63).

Criminal systems can be interpreted as a whole system (statutory rules) for functionalisation or operationalization or criminal contretization which as a whole system (statutory rules) which regulates how criminal law is enforced or operationalized concretely so that someone is subject to criminal (legal) sanctions.

The criminal justice system is closely related to the term "Organizing System for Criminal Justice" or the System of administration of a criminal justice. The word "organizer" is pengindonesiaan from administration. "Implementation" shows the existence of activities or activities of certain institutions to run or move what is the duty and obligation (function) of the institution, according to a procedure or procedure based on the applicable provisions, in achieving certain objectives .

Barda Nawawi Arif believes that the criminal justice system is essentially identical to the criminal law enforcement system. The law enforcement system is basically a system of power / authority to enforce the law. The power / authority to enforce this law can be identified with the term judicial power. Therefore the criminal justice system is essentially identical to the judicial power system in the field of criminal law which is implemented / realized in 4 (four) sub-systems, namely: (1) investigative power by investigative institutions; prosecution authorities by the public prosecuting agency; (3) the power of adjudication / decision by the judicial body; and (4) the power of the implementation of criminal law by executing executives. The four subsystems constitute an integral unit of criminal law enforcement system or often referred to as the term integrated criminal justice system or 
integrated criminal justice system.(Moh. Hatta, 2009: 41- 42).

Indonesia adheres to an integrated law enforcement system (Integrated Criminal Justice System) which is the legal spirit of the Criminal Procedure Code (KUHAP). This integration is philosophically an instrument for realizing the national goals of the Indonesian nation which has been formulated by the Founding Father in the 1945 Constitution, namely; protect society (social defense) in order to achieve social welfare.

In the criminal justice system in Indonesia police institutions, prosecutors, courts and prisons are known as "an inseparable part of each other. The four institutions in carrying out their roles as executors of the criminal justice system must work together and coordinate to combat crime. The prosecutor's office is in charge of prosecuting.

This prosecution stage is the stage of the prosecutor's institution, by giving full authority to the public prosecutor to carry out the prosecution. Prosecution is the act of the public prosecutor to delegate a criminal case to a competent district court in terms of and according to the method stipulated in the law with a request that it be examined and decided by a judge at a court hearing. (Rusli Muhammad, 2011: 64).

The position of the Prosecutor's institution in a criminal court determines a criminal proceeding process carried out. When the indictment was handed over to the court, an examination began at the court. Thus all depends on the public prosecutor in a criminal case being held in the courtroom. We can see this at least in Article 1 number 3 of Act Number 16 of 2004 concerning the Prosecutor's Office of the Republic of Indonesia. Article "reads:" Prosecution is the act of the public prosecutor to delegate the case to the competent district court in terms of and according to the method stipulated in the Criminal Procedure Code with a request that it be examined and decided by the judge in the court session.

Thus, it is very clear that the position of the prosecutor in criminal justice in Indonesia is crucial. It can be said that the prosecutor is at the 
forefront of investigating the liaison at the court. From that, it is very important for cooperation and coordination of all parties involved in the criminal justice system.

Based on Law Number 8 of 1981 (KUHAP) a systematic effort should be created. The criminal justice system should be integrated in one attitude and step towards the prevention and eradication of crime in society. Each component in the criminal justice process is not able to cope with the prevention and eradication of crime according to its own interests and institutions. Each component is a sub-system in the entire criminal justice system. (Lobby Lukman, 2002: 27).

Discussing the criminal justice system clearly speaks of law enforcement by the police, prosecutors, courts and prisons. In the police, how is the legal process starting from arrest and detention carried out on legal subjects who carry out legal actions based on the provisions of the law. At the prosecutor's office how the legal subject who commits a criminal act is demanded in accordance with the provisions of the existing law. While in the court process how does the judge through his decision establish a law that is fair to the sense of justice of the community. Finally, on the execution of how community institutions carry out guidance for legal subjects based on existing laws. Thus it becomes very clear that the criminal justice system cannot be separated from the provisions of existing laws, so that the criminal justice system can run well in realizing certainty, justice, and the benefit of law in society. Indeed, at this point the criminal justice system that was built and formed is a manifestation of law enforcement.

\section{The Role of the Public Prosecutor's Indictment in Corruption Law Enforcement}

Corruption comes from the Latin corruptusl corrupti. From Latin it goes down to various languages in Europe, such as corruption and corrupt in England, corruption in France and corruptie in the Netherlands. From these languages adapted into Indonesian became 
corruption. (Chatrina Darul Rosikah 2016: 1).

In Indonesia, corruption has developed rapidly and is considered an extraordinary crime. Corruption is considered destructive because it is detrimental to society and the state. Not only in Indonesia, in other countries there are also many criminal acts of corruption with various modes and operandi. In addition to economics and politics, corruption is also linked to public policy, international policy, social welfare and national development. (Chatrina Darul Rosikah, 2016: 1).

Corruption is the reality of acts of deviation from social and legal norms that are not desired by the community and threatened by state sanctions. Corruption as a form of abuse of position (position), power, an opportunity to fulfill self and / or group interests that oppose the common interest (community). (Soemanto, 2014: 81).

In the perspective of Islamic law corruption is an attempt to enrich oneself or others by breaking the law which is contrary to the principle of justice (al-'is), accountability (al- amanah), and responsibility in a position. Crime of corruption in Indonesia when viewed from the perspective of jinayat law in Islam, it is the same as the concept of ghulul (betrayal), al-ghasy (fraud), and risywah (bribe), al-hirabah (seizure), and al-ghasab (use of other people's rights without permission). (Fazzan, 2015: 1).

Crime of corruption is any action that aims to benefit oneself or another person or a corporation, misuse authority, opportunity or means available to him because of a position or position that can harm state profits or the country's economy is classified as a criminal act of corruption. (Fazzan, 2015: 1).

In Article 2 of Law Number 20 of 2001 concerning Corruption Crime it is stated that corruption is: "" Anyone who violates the law commits an act that enriches himself or a corporation that can harm state finances. While Article 3: Every person who aims to benefit himself or another person or a corporation, misuses the authority, opportunity or means available to him because of a position or position that can harm the 
state's finance or the country's economy. (Ridwan, 2014: 386-387).

In Article 2 of Law Number 31 Of 1999 in conjunction with Law Number 20 Of 2001 concerning Eradication of Criminal Acts of Corruption, there are several important elements, namely: (1) Everyone; (2) Fighting the Law; (3) Enrich themselves / others / corporations; (4) Can be detrimental to the state or economy of the nation Everyone is an individual including a corporation (Article 1 number 3 of Law number 31 of 1999 in conjunction with Law Number 20 of 2001 concerning the Eradication of Corruption), each person may also relate to position or civil servants. "Many of these civil servants misunderstood it, as if" only civil servants are those referred to in the employment law, even though the civil servants are so wide in scope, which is confirmed in Article 1 number two of the Law number 31 of 1999 jo Act No. 20 of 2001 concerning the Eradication of Corruption Crimes, which formulates: Civil Servants include: a. civil servants as referred to in the employment law; b. civil servants as referred to in the Criminal Code; $\mathrm{c}$. people who receive salaries or wages from state or regional finances $d$. people who receive salaries or wages from a corporation that receives assistance from state or regional finance; or e. people who receive salaries or wages from other corporations that use capital or facilities from the state or society. (Ridwan, 2014: 387).

Regarding civil servants, as mentioned in letter $\mathrm{b}$ above, Article 92 of the Criminal Code formulates: Officials / civil servants, including those selected in elections held based on general rules, as well as those who are not elected, being a member of the law-making body of a government body, people's representative body, which is formed by the Government or on behalf of the Government; so are all waterschap councilors, and all the heads of the original Indonesian people and heads of the Foreign East group, who exercise legitimate power. (Ridwan, 2014: 388).

The forms of corrupt behavior according to the Corruption 
Eradication Commission (2006) include the loss of state finances, namely acts against the law, selfenrichment and misuse of authority, opportunities, and available means. Other forms of corruption are bribes, embezzlement in office, extortion, fraudulent acts, conflicts of interest in procurement, and gratuities.(Listyo Yuwanto, 2015: 3).

Regarding the element of state financial losses as stated in Article 2 of Act Number 31 of 1999 in conjunction with Law Number 20 of 2001 concerning the Eradication of Corruption Crimes, the forms of financial losses of these countries can be described.

The forms of state financial losses include: the expenditure of a source or state or regional wealth (which can be in the form of money, goods) which should not be spent; expenditure of a source or wealth of a country or region greater than it should be according to applicable criteria; loss of source or wealth of the country or region that should have been received (including including receipt of counterfeit money, fictitious goods); receipt of resources or state assets or areas smaller or lower than what should be received (including receipt of damaged goods, inappropriate quality); the emergence of a state or regional obligation that is greater than it should be; loss of a state or regional right that should be owned or accepted according to applicable rules; and the rights of the country or region received are smaller than they should be received. (Mia Amiati Iskandar,2013: 81).

State financial losses are a reduction in money, or state property that is real and definite in number as a result of actions that are not in accordance with the law because they are carried out intentionally or negligently. (Muhammad Djafar Saidi, 2017: 122). In this section, state financial losses are seen as an element of corruption corruption. Its existence as an element of corruption offense is regulated in Article 2 paragraph (1) and Article 3 of the Law on Eradicating "Corruption Crime. Thus, the perspective on state financial losses is not based on legal aspects of state finance, but rather from aspects of criminal 
law.(Muhammad Djafar Saidi, 2017: 137).

State finances in question are all state assets in any form, which are separated or not separated, including all parts of the state's wealth and all rights and obligations arising from: First, being in control, management and accountability of state institutions, both at the central level and in the region; Second, are in the control, management, and accountability of State-Owned Enterprises or Regional-Owned Enterprises, foundations, legal entities, and companies that include state capital, or companies that include third party capital based on agreements with the State. (W. Riawan Tjandra, 2013: 9).

In handling various types of corruption crimes involving state finances, the government has issued various regulations. It is intended that the Indonesian state can be free from corruption. The regulations made were also supplemented by the establishment of various types of commissions to eradicate corruption. Just say for example the Corruption Eradication Commission.
Even when Megawati's government had formed the Corruption Eradication Commission (KPTPK). The establishment of this institution is a legal breakthrough for the stagnation of efforts to eradicate corruption in this country. This then became the forerunner to the establishment of the Corruption Eradication Commission (KPK). (Chatrina Darul Rosikah, 2016: 156). The Corruption Eradication Commission (KPK) was born as a milestone in the commitment to eradicate corruption, where the milestones were interpreted as: (1) blocks (wood, stone, etc.) mounted erect; (2) poles (houses, bridges, etc.). So the reforms in the fight to eradicate corruption with the birth of the Corruption Eradication Commission are expected to be the pillar of the nation's commitment which is represented not only by the government elite but also by the entire Indonesian people. Together striving with full body and soul to realize the commitment to fight and eradicate corruption to its roots so that future shared ideals to become a clean and free from corruption can be 
achieved. (Chatrina Darul Rosikah, 2016: 162).

The existence of reforms in the fight to eradicate corruption with the birth of the Corruption Eradication Commission is expected to become the pillar of the nation's commitment to be represented not only by the government elite but also by the entire Indonesian people. Together striving with full body and soul to realize the commitment to fight and eradicate corruption to its roots so that future shared ideals to become a clean and free from corruption can be achieved. (Chatrina Darul Rosikah, 2016: 162).

In the history of eradicating corruption, Indonesia also has Presidential Instruction No. 5 of 2004, eradicating corruption must be a priority. The performance of law enforcement agencies is a precondition for completing the eradication of corruption in Indonesia. Legal institutions to eradicate corruption and Article 27 paragraph (1) of the 1945 Constitution are legal institutions that support the eradication of criminal acts of corruption.(Mia Amiati Iskandar, 2013: 81).

In the Inpres specifically instructed the Attorney General to: First, optimize efforts to investigate and prosecute criminal acts of corruption to punish perpetrators and save state money. Second, prevent and provide strict sanctions against abuse of authority carried out by the Prosecutor (Public Prosecutor) in the context of law enforcement. Third, improve cooperation with the Republic of Indonesia National Police, in addition to BPKP, PPATK, and state institutions related to law enforcement efforts and restoring state financial losses due to corruption. (R. Widyo Pramono, 2017: 49).

Furthermore, the government also issued a National Strategy and National Action Plan for Eradicating Corruption (National Strategy and National Action Plan for PK) for 2010-2025 with the vision "The establishment of governance that is free from corrupt practices with the supportive capacity of national preventive and enforcement capacity 
and integrity.(R. Widyo Pramono, 2017: 49).

Quite a lot of legislation in Indonesia was made as an effort to eradicate corruption. This is a manifestation of the Indonesian government's desire to eradicate corruption, but there are still legal loopholes that corruptors can misuse to escape legal entanglement. (Sri Suwitri, 2007: 35). Besides that, from time to time the perpetrators of corruption do not want to go away from the social life of the community. In many reports in various national mass media we can see the perpetrators coming and going. Not yet finished the case one was decided by the court to come again the perpetrators of other corruption.

The act of corruption has touched all lines of people's lives and continues to develop in more complex and sophisticated forms so that it is difficult to eradicate. Even though government policy has been made with the establishment of legislation as part of a strategy to eradicate corruption, corruption still remains. This proves that it is not because of the absence of rules that corruption is rampant in Indonesia, but is caused by human factors that do not obey the rules.. (R. Widyo Pramono, 2017: 53).

To find out the causes of corruption, it is necessary to examine the stimulating factors, which underlie the occurrence of criminal acts of corruption. For example, corruption is related to the management of state finances, so the organizational aspect is the most dominant cause of corruption, in addition to ambiguistic factors of regulation and inadequate welfare problems. Another factor is the lack of supervision and lack of role models from the leadership. Weaknesses of management control systems, not just providing opportunities, even tend to have become a culture in covering corruption in an organization. State financial irregularities often occur from the time of preparation, planning, formation, and when implementing a state or regional government financial budget which is usually contained in a State Budget $(\mathrm{APBN})$ or Regional Budget 
(APBD). (R. Widyo Pramono, 2017: 45).

State financial losses are a reduction in money, or state property that is real and definite in number as a result of actions that are not in accordance with the law because they are carried out intentionally or negligently. (Muhammad Djafar Saidi, 2017: 122).

There is a loss of state finances in various types of corruption, so in the future there is a need for professionalism and integrity of law enforcers to deal with corruption more optimally. One of the institutions awaited its work is the Prosecutor's Office as the highest public prosecutor in Indonesia.

In the provisions of Law Number 16 of 2004 concerning the Prosecutor's Office of the Republic of Indonesia very brightly stated: Prosecutors have the authority to investigate corruption as contained in the provisions of Article 30 paragraph (1) letter $d$. The sound of Article 30 paragraph (1) letter d is the Prosecutor's Office conducting an investigation of certain criminal acts under the law. "In the explanation referred to as certain criminal acts, namely the criminal acts of Corruption and Violations of Human Rights (HAM). From the provisions of the Article above, in a formal juridical manner the Attorney General's Office has the authority to investigate corruption and human rights violations.

In relation to criminal justice, the duty and authority of the prosecutor's office are regulated in criminal procedural law, namely Law Number 8 of 1981 concerning Criminal Procedure Law (KUHAP), while in relation to its own institutions it is regulated in Law Number 16 of 2004 concerning Republican Prosecutors' Office Indonesia. In the context of corruption, referring to Law Number 20 of 2001 concerning Corruption Crime. From each of these legislation in principle is the result of the development of the previous legislation.

Institutions that are authorized to handle investigations, investigation and prosecution of criminal acts of corruption can be carried out by various law enforcement agencies, 
namely the Police, the Prosecutor's Office and the Corruption Eradication Commission. This is regulated both in the Criminal Procedure Code, Law Number 2 of 2002 and Law Number 30 of 2002 concerning the Corruption Eradication Commission. In addition, the examination in his court can also be tried in a public court and a court of corruption. (Firman Wijaya, 2008: 61).

Essentially, the prosecutor as an institution that has the authority to deal with corruption can act both as a public prosecutor who gets the results of an investigation of the Police Examination Report (BAP) on corruption and can also act as a direct investigator of corruption. (Firman Wijaya, 2008: 65).

Prosecutors at the prosecutor's institution must be able to carry out the duties of the state in terms of freeing the country or at least reducing corruption, of course, by providing maximum demands in the indictment. This aims to achieve legal certainty, legal justice and the benefit of the law. Repressive and preventive eradication of corruption must be carried out by the prosecutor's institution, both by the Attorney General's Office, the High Prosecutor's Office and the District Attorney's Office.

An indictment can be prepared properly by the public prosecutor if the public prosecutor pays attention to the material requirements "(Article 143 paragraph (2) letter b KUHAP.) And formal requirements (Article 143 paragraph (2) letter a KUHAP," "from a letter charges. If these two conditions are ignored, it is possible that the prosecutor's indictment will be in vain. As for the charges of the public prosecutor who did not fulfill the material requirements, the legal consequences of the indictment were "null and void" as clearly stipulated in Article 143 paragraph (3) of the Criminal Procedure Code. If an indictment does not meet formal requirements, the legal consequences of the indictment can be declared "unacceptable". The broader consequences of being unable to accept or cancel by law the indictment, it will ignore the sense of legal justice, obscure the meaning of legal certainty and the loss of legal 
benefits as one of the objectives of the law in the rule of law.

According to Sudikno Mertokusumo, legal certainty is a guarantee that the law is implemented, that those who are entitled by law can obtain their rights and that the verdict can be implemented. Although legal certainty is closely related to justice, but the law is not synonymous with justice. Law is general, binding everyone, generalizing, while justice is subjective, individualistic and does not generalize. (Sudikno Mertokusumo, 2007: 160).

In understanding the value of legal certainty that must be considered is that the value has a close relationship with positive legal instruments and the role of the state in actualizing it in positive law. (Fernando M. Manulang, 2007: 95).

The implementation and enforcement of the law must also pay attention to its benefits and uses for the community. Because the law is actually made for the benefit of the people (humans). Therefore the implementation and enforcement of the law must benefit the community.
Do not let the implementation and enforcement of the law harm the community, which in turn will cause unrest. (Titik Triwulan Tutik2006: 228).

For this reason, the public prosecutor must be careful, thorough and careful in making an indictment. Because mistakes due to inadvertent, inaccurate and inaccurate have fatal consequences for efforts to eradicate various forms of crime, especially criminal acts of corruption. In the future, everything that is good must be maintained by the public prosecutor. Things that are less than optimal in making an indictment should be a concern to get better.

In order for the indictment to be arranged properly, correctly and perfectly, then a public prosecutor must: 1) master the event perfectly (from BAP). In order to master the course of the events being indicted, the public prosecutor must study the BAP received from the investigator well and thoroughly. The course of events to be included in the indictment is found in the BAP (especially on the resume of the investigator). The more perfect the 
public prosecutor has mastered all aspects of the event, the better the indictment will be made. 2) good mastery of material law (crime), especially those close to the events that occurred. Good mastery of material law, including also concerning the science or legal doctrine and jurisprudence regarding the closest criminal offense to be indicted in the indictment. 3) master the criminal procedure law (regarding the indictment) properly. Each indictment has a standard that must be met so that the indictment is made good and perfect. Besides avoiding the exception, the perfection of the indictment can also facilitate the process of verification in the court session. 4) skilled / art. Skills and proficiency in making an indictment is an art that can be mastered if done repeatedly through exercises. (Adami Chazawi, 2007: 36-37).

Including the important thing from all the problems above is how to increase the professionalism of the public prosecutors to be improved, this is considering the growing crime in society. Then also cooperation between other law enforcement institutions. It is necessary to increase professionalism and increase sustainable cooperation between law enforcement in the Indonesian criminal justice system. This is intended so that law enforcement efforts can be better in order to achieve legal objectives. Then also, given the important meaning of the indictment, the public prosecutor must increase the accuracy and precision in formulating the indictment. Because the indictment becomes an important point can be convicted or not someone is accused by a judge. When the indictment is made inaccurately or inaccurately it will result in the charges being blurred and null and void by law.

\section{Conclusion}

a) The role of the prosecutor's office as a law enforcement agency in the Indonesian criminal justice system is a role in law enforcement to conduct investigations into criminal acts under the law. As law enforcers in the criminal justice system, 
the existence of the prosecutor's office is awaited in establishing Indonesia as a country that always places a sense of justice, legal certainty, and the benefit of the law in social life.

b) The role of the public prosecutor's indictment in enforcing corruption law is confirmed in the provisions of Article 30 paragraph (1) letter d. The article explains that the prosecutor is an institution that conducts investigations into certain criminal acts. In the explanation, what is meant by certain criminal acts is, among others, the crime of corruption. Thus, the prosecutor's office can carry out ways to eradicate corruption through repressive and preventive efforts, both those carried out by the Attorney General's Office, the High Prosecutor's Office and the District Prosecutor's Office. Efforts to eradicate corruption can be carried out by the prosecutor's office in a repressive and preventive manner, of course, by making the best possible indictments and prosecuting corruptors with maximum demands.

\section{References}

\section{Books}

Chazawi, Adami, 2007, Kemahiran dan Keterampilan Praktik Hukum Pidana, Malang: Bayumedia Publishing.

Arif, Barda Nawawi, Kapita Selekta Hukum Pidana Tentang Sistem Peradilan Pidana Terpadu, (Semarang: BP Universitas Diponegoro, 2007). Sebagaimana dikutip Moh. Hatta, Beberapa Masalah Penegakan Hukum Pidana Umum \& Pidana Khusus, (Yogyakarta: Liberty, 2009).

Rosikah, Chatrina Darul, dan Dessy Marliani Listianingsih, Pendidikan ANTIKORUPSI, Kajian Antikorupsi Teori dan Praktik, (Jakarta: Sinar Grafika, 2016).

Zulfa, Eva Achjani, Anugerah Rizki Akbari, Zakky Ikhsan Samad, Perkembangan Sistem Pemidanaan dan Sistem Pemasyarakatan, (Depok: Rajawali Pers, 2017).

Manulang, Fernando M, Mengapai Hukum Berkeadilan, (Jakarta: Kompas, 2007).

Wijaya, Firman, Peradilan Korupsi Teori dan Praktik, (Jakarta: 
Penaku bekerjasama dengan Maharini, 2008).

Teguh, Harrys Pratama, dan Usep Saepullah, Teori dan Praktik Hukum Acara Pidana Khusus, (Bandung: Pustaka Setia,2016).

Husin, Kadri, dan Budi Rizki Husin, Sistem Peradilan Pidana Di Indonesia, (Jakarta: Sinar Grafika, 2016).

Lukman, Lobby, Pidana dan Pemidanaan, (Jakarta: Detacom, September 2002), hal. 27. Sebagaimana dikutip Moh. Hatta, Beberapa Masalah Penegakan Hukum Pidana Umum \& Pidana Khusus, (Yogyakarta: Liberty, 2009).

Saidi, Muhammad Djafar, dan Eka Merdekawati Djafar, Hukum Keuangan Negara Teori dan Praktik, (Jakarta: Rajawali Pers, 2017).

Iskandar, Mia Amiati, Perluasan Penyertaan Dalam Tindak Pidana Korupsi Menurut UNCATOC 2000 dan UNCAC 2003, (Jakarta: Referensi, 2013).

Hatta, Moh, Beberapa Masalah Penegakan Hukum Pidana Umum \& Pidana Khusus, (Yogyakarta: Liberty, 2009).

Atmasasmita, Romli, Sistem Peradilan Pidana; Perspektif Eksistensialisme dan Abilisionisme, Cet II revisi, (Bandung: Bina Cipta, 1996).
Muhammad, Rusli, System Peradilan Pidana Indonesia, (Yogyakarta: UII Pres, 2011).

Rizky, Randy, dan Lukman Hakim, Seminar Nasional Reformasi Birokrasi Dalam Upaya Pencegahan Korupsi, APEKSI bekerjasama dengan PMC di Hotel Borobudur, Jakarta, 13 Nopember 2009. Sebagaimana dikutip oleh Mia Amiati Iskandar, Perluasan Penyertaan Dalam Tindak Pidana Korupsi Menurut UNCATOC 2000 dan UNCAC 2003, (Jakarta: Referensi, 2013).

Pramono, R. Widyo, Pemberantasan Korupsi Dan Pidana Lainnya Sebuah Perspektif Jaksa Dan Guru Besar, (Jakarta: Kompas, 2017).

Soekanto, Soerjono, \& Sri Mamudji, Penelitian Hukum Normatif, Suatu Tinjauan Singkat, (Jakarta: Rajawali, 1985).

Mertokusumo, Sudikno, Penemuan Hukum Sebuah Pengantar, (Yogyakarta: Liberty, 2007).

Tutik, Titik Triwulan, Pengantar Ilmu Hukum, (Jakarta: Prestasi Pustaka, 2006).

Tjandra, W. Riawan, Hukum Keuangan Negara, (Jakarta: Grasindo,2013).

Anwar, Yesmil dan Adang, Sistem Peradilan Pidana, Konsep, Komponen \& Pelaksanaannya Dalam Penegakan Hukum di 
Indonesia, (Bandung: Widya Padjadjaran, 2009).

\section{Laws and Regulations}

Undang-Undang Nomor 16 tahun 2004 tentang Kejaksaan Republik Indonesia.

Undang-Undang Nomor 2 tahun 2002 tentang Kepolisian Negara Republik Indonesia.

Undang-Undang Nomor 48 tahun 2009 tentang Kekuasaan Kehakiman Republik Indonesia.

Undang-Undang Nomor 12 tahun 1995 tentang Lembaga Pemasyarakatan.

Undang-Undang Nomor 8 tahun 1981 tentang Kitab UndangUndang Hukum Acara Pidana.

Undang-Undang Nomor 20 tahun 2001 tentang Tindak Pidana Korupsi.

\section{Journals}

Didit Ferianto Pilok, Kedudukan Dan Fungsi Jaksa Dalam Peradilan Pidana Menurut Kuhap, Jurnal Lex Crimen, Vol. II/No. 4/Agustus/2013.

Wicaksana, Dio Ashar, Kedudukan Kejaksaan RI dalam Sistem Hukum Tata Negara Indonesia, Via Justitia, Vol. 1 / No. 1 / Maret 2013.

Fazzan, Korupsi Di Indonesia Dalam Perspektif Hukum Pidana Islam, Jurnal Ilmiah ISLAM
FUTURA Vol. 14. No. 2, Februari 2015.

Yuwanto, Listyo, Profil Koruptor Berdasarkan Tinjauan Basic Human Values, Jurnal Antikorupsi Integritas, 01 Volume 1 November 2015.

Ridwan, Upaya Pencegahan Tindak Pidana Korupsi Melalui Peran Serta Masyarakat, Kanun Jurnal Ilmu Hukum Ridwan No. 64, Th. Xvi, Desember, 2014.

Soemanto, RB, Sudarto, Sudarsana, Pemahaman Masyarakat Tentang Korupsi, Yustisia Vol. 3 No. 1 Januari - April 2014.

Indrawan, Rudi, H. Ahmad Syaufi Rechtidee, Kinerja Aparat Penegak Hukum dalam Penanganan Perkara Tindak Pidana Korupsi di Provisi Kalimantan

Selatan,Rechtidee,Vol. 11. No. 1, Juni 20161.

Suwitri, Sri, Pemberantasan Korupsi Di Indonesia : Sebuah Upaya Reformasi Birokrasi, Dialogue JIAKP, Vol. 4, No. 1, Januari 2007. 